\title{
Effect of beneficiary participation in program design and implementation on satisfaction and acceptability among internally displaced persons in Borno, Nigeria
}

\author{
Igbaver Isaac Ieren ${ }^{1 *}$ (D), Salome Kabuk-Agbadu ${ }^{2}$ and Chukwuma Umeokonkwo ${ }^{1,3}$
}

\begin{abstract}
Insurgency and other security challenges have intensified across Nigeria with a resultant displacement of over a million people from over 100,000 households who depend on interventions from government and non-governmental organizations for survival since 2009. We conducted the study to determine the level of involvement of the displaced persons in planning, implementation and review of these interventions, and the effect of the participation on satisfaction with the interventions among camp dwellers in selected camps in Borno, Nigeria. A total of 278 internally displaced persons (IDPs) across 9 IDP camps were surveyed using an interviewer-administered questionnaire. Data was collected using Android-based Open Data Kit (ODK), exported into Microsoft Excel, and analyzed with SPSS version 21. Out of the 278 respondents, 143 (51.4\%) were male, 82 (29.5\%) respondents were within the age bracket of 26-35 years and above (mean age $38.9 \pm 12.3$ ), over $78 \%$ were married, and $29.9 \%$ were involved in trading before their displacement. Among the respondents, 256 (92.1\%) had benefitted from at least one intervention during their stay in the IDP camps. Over $96 \%$ of the beneficiaries were female, compared to $87.4 \%$ of males, which was statistically significant $(p<0.05)$. All the respondents within the age group 26-35 years and above 45 years old who had received information about the interventions were satisfied, and this finding was statistically significant $(p<0.05)$. Overall, $91.5 \%$ of respondents who had benefitted from previous interventions would like to be involved in all the intervention stages (planning, implementation, and review). In comparison, $100 \%$ of IDPs who benefitted from previous interventions would like to be involved in the implementation, and 96.8\% of them would like to be involved in planning the proposed interventions. To ensure maximum coverage, and that optimum benefit is derived from development projects, beneficiaries should be involved in all stages of the project cycle.
\end{abstract}

Keywords: Borno, Insurgency, Internally displaced persons, Satisfaction, Nigeria, Beneficiaries, Participation

\section{Introduction}

Nigeria has experienced escalated levels of insecurity due to insurgency since 2009 (Gilbert 2014). The insurgency is predominant in Northeastern Nigeria and the Lake Chad Basin countries, described as the "headquarter of insurgency" (Albert 2017). This crisis has led to killings

\footnotetext{
* Correspondence: agbaduisaac@yahoo.com

${ }^{1}$ African Field Epidemiology Network, Abuja, Nigeria

Full list of author information is available at the end of the article
}

(Shuaibu et al. 2015) and the displacement of several people from their ancestral homes into temporary camps within and across the country's borders. As of 2019, it was estimated that over 1.8 million people were still displaced in Northeastern Nigeria, with over $80 \%$ of them being found in Borno, and needing humanitarian support (OCHA 2019). The displaced are mostly the vulnerable age groups such as the elderly, women, and children (Olanrewaju et al. 2018). Displaced persons in these 
camps are vulnerable and exposed to many crises ranging from food shortages, poor access to education, poor personal hygiene, shortage of potable water, diseases, and psychological trauma due to loss of loved ones and means of livelihood (Adewale 2016; Akuto 2017; Olanrewaju et al. 2018).

The sudden displacement of people who are, often, non-disabled working people could lead to a dependent situation due to loss of means of livelihood (Oyefara and Alabi 2016). The dependence on aid itself creates an emotional and psychological crisis in most humanitarian situations with victims feeling unprotected (Shehu and Abba 2020). The non-involvement of the IDPs in the decision-making about how their problems are addressed can add another layer of complexity, especially where the humanitarian agencies involved in the decision-making processes are neither religion nor culture-sensitive (Shehu and Abba 2020).

It has been documented that client participation can lead to improved satisfaction, better program design, and implementation. It is also known that community participation can draw from the already existing community resource and assets to address the community's felt need (OCHA 2017).

These displaced persons are usually provided with temporary shelter in camps while other interventions are further designed to mitigate the IDPs' challenges by the government and other partner agencies. These agencies often step in, with pre-designed interventions, to reduce the hardships of the displaced persons. The interventions are initiated and designed using a top-to-bottom approach with minimal involvement of the beneficiaries (Thwala 2010). This practice could affect acceptance, satisfaction, and sustainability of these interventions (Ofuoku 2011; Chirenje et al. 2013; Olori and Okide 2014). Laah et al. (2014), Abdullahi et al. (2014), and Bappi et al. (2018) reported that most of the community involvement in project development and implementation were education and consultation without involving the communities in designing, planning, and improvement to ensure sustainability.

This study aims to determine the level of beneficiaries' participation in the IDP camps interventions and how their involvement affects their satisfaction with the interventions, from which they have benefitted.

\section{Methods}

This study was conducted in Borno state, Northeastern Nigeria. The state shares borders with Adamawa state to the south, Yobe state to the west, Cameroun, and the Chad Republic to the east and the Niger Republic to the north. The state is located on coordinates $11^{\circ} 30^{\prime} \mathrm{N}$ and $13^{\circ} 00^{\prime} \mathrm{E}$ with an area of $70,898 \mathrm{~km}^{2}$ and has a population of approximately 7,000,000 people (Babagana
2017). The Northern part of the state is home to majorly Kanuri and Shuwa speaking people who are predominantly Muslims. In the Southern part of the state, the commonly spoken languages include Marghi, Chibok, and Bura (Chama et al. 2010). The main occupation is agriculture, both subsistent and commercial, but some are involved in fishing, knitting, and trans-boundary trade with the neighbouring countries. Administratively, the state has 27 local government areas (LGAs) with a majority of them having varying levels of accessibility due to insurgents' activities (ACAPS, 2017).

The study design was longitudinal and cross-sectional involving 278 caregivers in 9 IDP camps across 3 LGAs: Bama, Jere, and Maiduguri LGAs. Data was collected using interviewer-administered questionnaire configured on Android devices using Open Data Kit (ODK). Data collection teams were trained on the use of Android devices to collect data and the administration of electronically configured questionnaire before deployment. The questionnaire was designed to elicit information on the five [food, healthcare, education, livelihood, water sanitation, and hygiene (WASH)] out of the seven critical areas for humanitarian interventions.

The information elicited included socio-demographic data, duration of stay on the IDP camps, being beneficiaries of any intervention since arriving camp, involvement in intervention planning, implementation, and review. The willingness of the respondents to participate in intervention planning, implementation, and review was also assessed. Written informed consent was sought from the caregivers, and only those who consented to participate in the survey were interviewed. The questionnaire on ODK was piloted to ensure there was no ambiguity in the tool and that the data collectors were familiar with the questionnaire administration on android devices before the commencement of fieldwork.

\section{Data analysis}

Data collected through the Android/electronic platform was submitted to a central server. The collected data was downloaded to Microsoft Excel and exported to Statistical Package for Social Sciences (SPSS) version 21 for cleaning and analysis. The analysis involved univariate and bivariate approaches, including frequency, percentages, and comparative analysis with test statistics (Chi-square). Chi-square was used to assess the relationship between some of the critical variables and satisfaction, which was defined as a measure of how useful the respondents perceived interventions. The summarized data was presented in tables and charts as appropriate.

\section{Results}

Out of the 278 respondents who participated in this study, 143 (51.4\%) were males, while 48.6\% were females. 
About one-third (29.5\%) of the respondents were $>44$ years. The participants' mean age was $38.9 \pm 12.3$ years, and a majority (65.8\%) were of Kanuri ethnic group. About 78\% (78.4\%) of the respondents were married. Islam was the most predominant religion among the respondents (97.8\%), and $29.9 \%$ were involved in farming and fishing before their displacement. About $68.0 \%$ of these respondents had lived in the IDP camps for more than 5 years, and $91.0 \%$ had children with them in the IDP camps (Table 1).

Among respondents, 256 (92.1\%) had benefitted from at least one intervention while living in the IDP camps (Fig. 1). Distribution of the benefitting respondents

Table 1 Socio-demographic characteristics of respondents of IDP Camps Respondents in Borno State

\begin{tabular}{|c|c|c|}
\hline Characteristics & Frequency & Percent \\
\hline \multicolumn{3}{|l|}{ Sex } \\
\hline Male & 135 & 48.6 \\
\hline Female & 143 & 51.4 \\
\hline \multicolumn{3}{|c|}{ Age categorized (years) } \\
\hline$<26$ & 59 & 21.2 \\
\hline $26-35$ & 82 & 29.5 \\
\hline $36-45$ & 70 & 25.2 \\
\hline $46+$ & 67 & 24.1 \\
\hline \multicolumn{3}{|l|}{ Ethnicity } \\
\hline Kanuri & 183 & 65.8 \\
\hline Shuwa & 39 & 14.0 \\
\hline Hausa & 16 & 5.8 \\
\hline Other & 40 & 14.4 \\
\hline \multicolumn{3}{|l|}{ Marital status } \\
\hline Single & 20 & 7.2 \\
\hline Married & 218 & 78.4 \\
\hline Divorced & 10 & 3.6 \\
\hline Widowed & 30 & 10.8 \\
\hline \multicolumn{3}{|c|}{ Occupation before displacement } \\
\hline Farming/fishing & 43 & 15.5 \\
\hline Housewife & 33 & 11.9 \\
\hline Trading & 83 & 29.9 \\
\hline Knitting & 36 & 12.9 \\
\hline Public service & 18 & 6.5 \\
\hline Other & 65 & 23.4 \\
\hline \multicolumn{3}{|c|}{ Duration of stay on the camp (years) } \\
\hline$<5$ & 89 & 32.0 \\
\hline$\geq 5$ & 189 & 68.0 \\
\hline \multicolumn{3}{|c|}{ Do you have children } \\
\hline Yes & 253 & 91.0 \\
\hline No & 25 & 9.0 \\
\hline
\end{tabular}

shows that about $67 \%$ of them benefitted from nutrition (distribution of food items) (79.1\%), vaccination (68.0\%), and water supply (62.9\%, Fig. 2).

Table 2 shows the distribution of respondents who have benefitted from at least one intervention by their socio-demographic characteristics. Over $96 \%$ of the female respondents had benefitted from the interventions compared to $87.4 \%$ of males, and this difference was statistically significant $(p<0.05)$. A higher proportion of older participants had received at least one intervention than younger respondents aged 34 years and below. However, this difference in proportion was not statistically significant $(p=0.722)$. More respondents who had been married (including married, divorced, and widowed), had children, and had lived for more than 5 years in the IDP camps have benefitted from the camp intervention than those who were single, had no children, and had lived in the IDP camps for $<5$ years. These findings were statistically significant $(p<0.05)$.

Among the IDP camp dwellers who benefitted from the interventions, $77.7 \%$ reported being very satisfied with the intervention while $1.6 \%$ were unsatisfied. Most (47.7\%) of the respondents chose nutrition (food distribution) as the most satisfying intervention in terms of usefulness and followed by vaccination services (14.5\%) and personal hygiene supplies (12.5\%). In comparison, $1.4 \%$ chose the distribution of seedlings and other farming implements as the most satisfying intervention (Table 3).

Among the respondents who had benefitted from IDP camp intervention before the survey, 156 (60.9\%) were consulted before the intervention. Among those who had received information about the intervention, 58.1\% were informed by NGO representatives/staff in the camp. The majority $(41.7 \%)$ got the information about the projects at the planning stage before commencement (Table 4). For respondents who were not consulted about the intervention, $62 \%$ responded that they would prefer food distribution ahead of the other interventions that they had received (Fig. 3).

More female $(100 \%)$ of those who got information about the interventions report that they were in line with their desire compared to the male respondents (96.0\%). This finding was, however, not statistically significant $(p>0.05)$. All the respondents within the age group 25-35 years and above 45 years old who had received information about the interventions responded that the interventions were in line with their desire, which was statistically significant $(p<0.05)$. In the same vein, $100 \%$ of the respondents who were single, divorced, widowed, had no children at the time of the survey responded that the interventions were in line with their desire. About $98 \%$ of the respondents who lived in the camps for more than 5 years accepted that the 

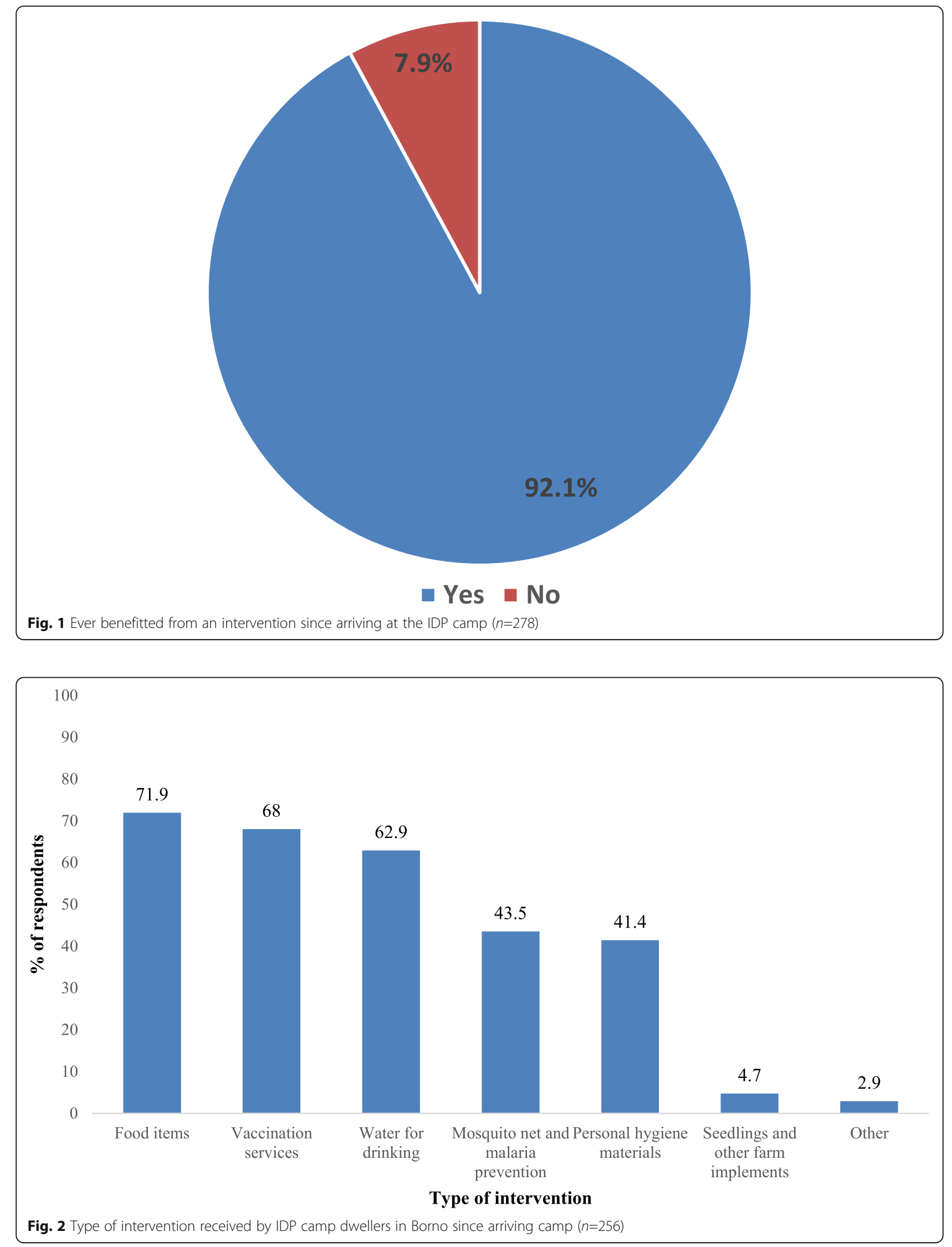
Table 2 Distribution of the participants who had ever benefitted from intervention provided in the camp ( $n=256)$

\begin{tabular}{|c|c|c|c|c|}
\hline \multirow[t]{2}{*}{ Characteristics } & \multicolumn{2}{|c|}{ Ever benefitted from at least intervention } & \multicolumn{2}{|c|}{ Statistics } \\
\hline & Yes (\%) & No. (\%) & $x^{2}$ & $p$ value \\
\hline Gender & & & 7.884 & $0.005^{*}$ \\
\hline Male & $118(87.4)$ & $17(12.6)$ & & \\
\hline Female & $138(96.5)$ & $5(3.5)$ & & \\
\hline Age categorized (years) & & & 4.775 & 0.189 \\
\hline$<26$ & $51(86.4)$ & $8(13.6)$ & & \\
\hline $26-35$ & 79 (96.3) & $3(3.7)$ & & \\
\hline $36-45$ & $65(924.9)$ & $5(7.1)$ & & \\
\hline $46+$ & $62(91.0)$ & $(98.0)$ & & \\
\hline Marital status & & & 9.834 & $0.020^{*}$ \\
\hline Single & $15(75.0)$ & $5(25.0)$ & & \\
\hline Married & $202(92.7)$ & $16(97.3)$ & & \\
\hline Divorced & $10(100.0)$ & $0(0.0)$ & & \\
\hline Widowed & $29(96.7)$ & $1(3.3)$ & & \\
\hline Do you have children & & & 5.507 & $0.019^{*}$ \\
\hline Yes & $236(93.3)$ & $17(6.7)$ & & \\
\hline No & $20(80.0)$ & $5(20.0)$ & & \\
\hline Duration of stay on the camp (years) & & & 0.868 & 0.351 \\
\hline$<5$ & $80(89.9)$ & $9(10.1)$ & & \\
\hline $5+$ & 176 (93.1) & $13(6.9)$ & & \\
\hline
\end{tabular}

*Statistically significant at $95 \% \mathrm{Cl}$

interventions were in line with their desire. These findings were also not statistically significant $(p>0.05)$ and are represented in Table 5 .

Effective project implementation to reach the beneficiaries' expectancies involves the participation of those for whom the interventions are targeted. In this study,

Table 3 Level of satisfaction with the interventions among IDPS in Borno, Nigeria

\begin{tabular}{lll}
\hline & Frequency & Percentage \\
\hline Most satisfying intervention $(n=256)$ & 122 & 47.7 \\
Food items & 13 & 5.1 \\
Educational materials & 4 & 1.6 \\
LLIN & 32 & 12.5 \\
Personal hygiene materials & 23 & 9.0 \\
Water for drinking and cooking & 37 & 14.5 \\
Vaccination services & 3 & 1.4 \\
Seedlings and other farm implements & 20 & 7.8 \\
Other & which you benefitted from \\
$\begin{array}{l}\text { Overall, how useful were the interventions } \\
(n=256)\end{array}$ & 199 & 77.7 \\
Very useful & 48 & 18.8 \\
Somewhat useful & 5 & 2.0 \\
Not too useful & 4 & 1.6 \\
Not useful at all & & \\
\hline
\end{tabular}

Table 4 Beneficiaries consultation prior to commencement of project among IDPs in Borno

\begin{tabular}{lcl}
\hline Characteristics & Frequency & Percentage \\
\hline Were you contacted about the intervention $(n=256)$ & \\
Yes & 156 & 60.9 \\
No & 100 & 39.1
\end{tabular}

Person who notified the respondent about the intervention $(n=156)$

$\begin{array}{lll}\text { NGO representative } & 91 & 58.3 \\ \text { IDP camp leadership } & 34 & 21.8 \\ \text { Government/health officials } & 21 & 13.5 \\ \text { Friends/family members } & 10 & 6.4\end{array}$

Stage at which the respondents got informed about the intervention $(n=156)$

$\begin{array}{lll}\text { Planning } & 65 & 41.7 \\ \text { Implementation } & 33 & 21.2 \\ \text { Review } & 5 & 3.2 \\ \text { At all stages } & 53 & 34.0\end{array}$

Intervention in line with respondents' desire $(n=156)$

$\begin{array}{lll}\text { Yes } & 153 & 98.1\end{array}$

$\begin{array}{lll}\text { No } & 3 & 1.9\end{array}$ 


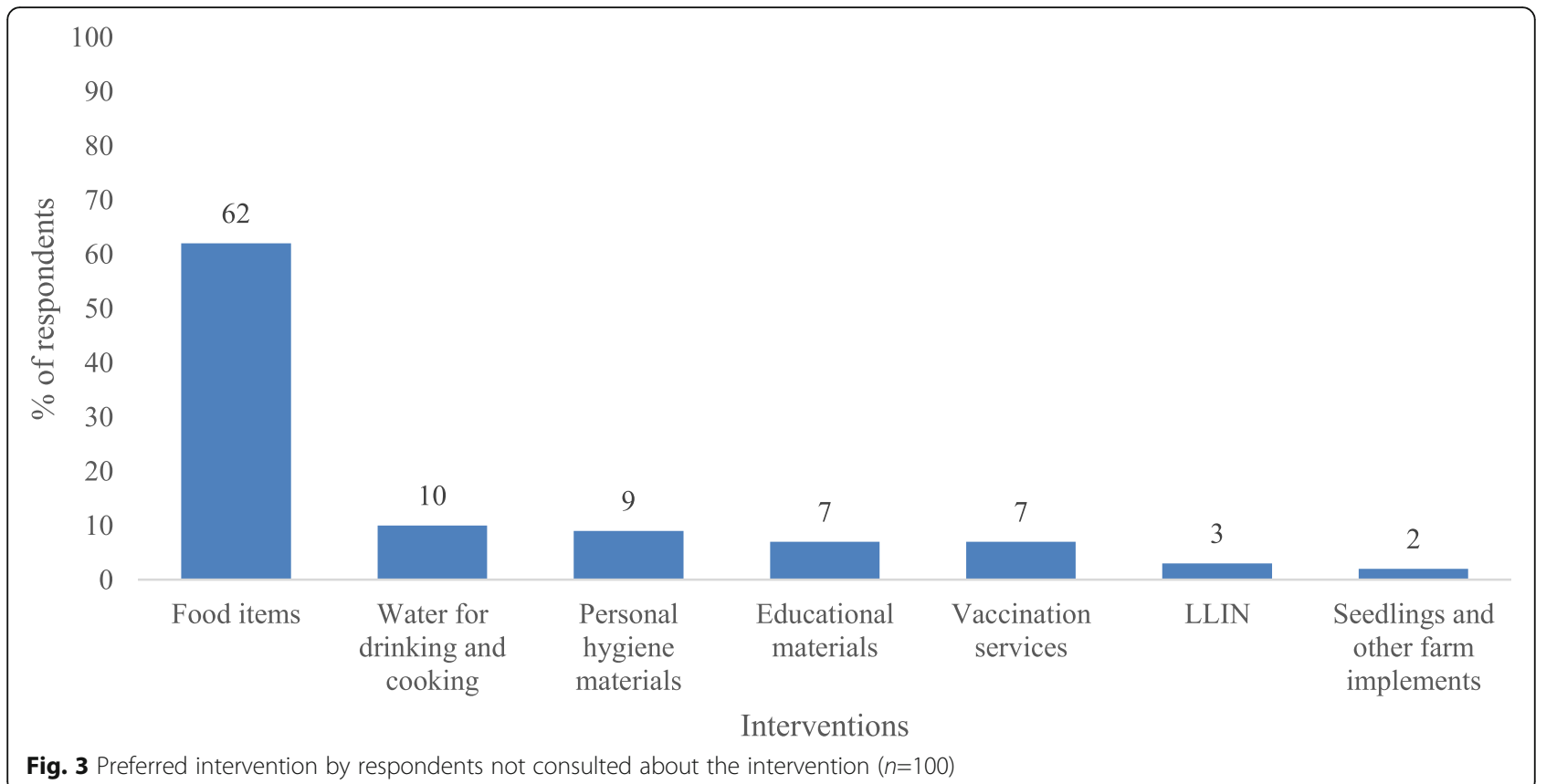

Table 5 Beneficiaries who were informed about the intervention and satisfaction with the intervention ( $n=156)$

\begin{tabular}{|c|c|c|c|c|}
\hline \multirow[t]{2}{*}{ Characteristics } & \multicolumn{2}{|c|}{ Intervention in line with respondents' desire } & \multicolumn{2}{|c|}{ Statistics } \\
\hline & Yes (\%) & No. (\%) & $x^{2}$ & $p$ value \\
\hline Gender & & & 3.304 & 0.069 \\
\hline Male & $72(96.0)$ & $3(4.0)$ & & \\
\hline Female & $81(100.0)$ & $0(0.0)$ & & \\
\hline Age categorized (years) & & & 8.303 & $0.040^{*}$ \\
\hline 25 and below & $28(100.0)$ & $0(0.0)$ & & \\
\hline $26-35$ & $48(100.0)$ & $0(0.0)$ & & \\
\hline $36-45$ & $39(92.9)$ & $3(7.1)$ & & \\
\hline$>45$ & $38(100.0)$ & $0(0.0)$ & & \\
\hline Marital status & & & 0.529 & 0.912 \\
\hline Single & $6(100.0)$ & $0(0.0)$ & & \\
\hline Married & $130(97.7)$ & $3(2.3)$ & & \\
\hline Divorced & $4(100.0)$ & $0(0.0)$ & & \\
\hline Widowed & $13(100.0)$ & $0(0.0)$ & & \\
\hline Do you have children & & & 0.144 & 0.705 \\
\hline Yes & $146(98.0)$ & $3(2.0)$ & & \\
\hline No & $7(100.0)$ & $0(0.0)$ & & \\
\hline Duration of stay on the camp (years) & & & 0.002 & 0.962 \\
\hline$<5$ & $53(98.1)$ & $1(1.9)$ & & \\
\hline $5+$ & $100(98.0)$ & $2(2.0)$ & & \\
\hline
\end{tabular}

*Statistically significant at $95 \% \mathrm{Cl}$ 
we surveyed the beneficiaries' level of involvement in project planning, implementation, and review. Among the IDP camp dwellers surveyed, $46.8 \%$ preferred to be involved in all the stages of the proposed interventions (i.e., planning, implementation, and review). About a third (33.5\%) of the respondents would prefer to be involved at the planning stage. In comparison, $2.9 \%$ felt they were not interested in being involved in the project activities apart from being just beneficiaries (Fig. 4).

Overall, 91.5\% of respondents who had benefitted from previous interventions would like to be involved in all the stages of the interventions (planning, implementation, and review). All (100\%) of IDP camp dwellers who were beneficiaries of previous projects would like to be involved in the implementation, and $96.8 \%$ of them would like to be involved in planning for the proposed interventions (Table 6).

Among the respondents who were satisfied with the previous interventions received, $100 \%$ responded that they would like to be involved in the implementation, and review stages, compared to $97.0 \%$ would prefer to be involved in all intervention/project stages (Table 7).

\section{Discussion}

From the findings, more female (51.4\%) respondents participated in the study compared to their male counterparts. Most (95\%) of the respondents had children. These findings are in concordance with Surajo et al.
(2019) report that more females were affected by the insurgency in Borno and other parts of Northeastern Nigeria. Mohammed (2017) while profiling victims of Boko Haram insurgency living in IDP camps in Maiduguri metropolis documented that about 30,236 women and 35,132 girls were victims of insurgency and living in IDP camps compared to 18,618 men and 27,252 boys in these same ICP camps. Among these women, $24 \%$ were lactating mothers with children less than 5 years old. The displacement tracking and monitoring report (DTM, June 2020) for week 32 indicated that $53 \%$ of the displaced persons in the Northeast were females and that $38 \%$ of them were within the ages of $18-59$ years, many of whom will have children accompanying them during the travail. This distribution could be attributed to the fact that in the affected areas, men often stay back to defend the communities against insurgents while supporting the women, children, and the elderly to flee for safety, usually to camps of internally displaced persons.

Several organizations, comprising government agencies and non-governmental organizations, have been involved in providing support such as relief materials to the displaced persons across the country including the Northeastern (which includes Borno) (DTM 2020). This effort could be why most of the respondents confirm they have benefitted from at least one intervention across the pillars (shelter, nutrition, water supply, protection, livelihood, and health). Nutrition support in the form of food

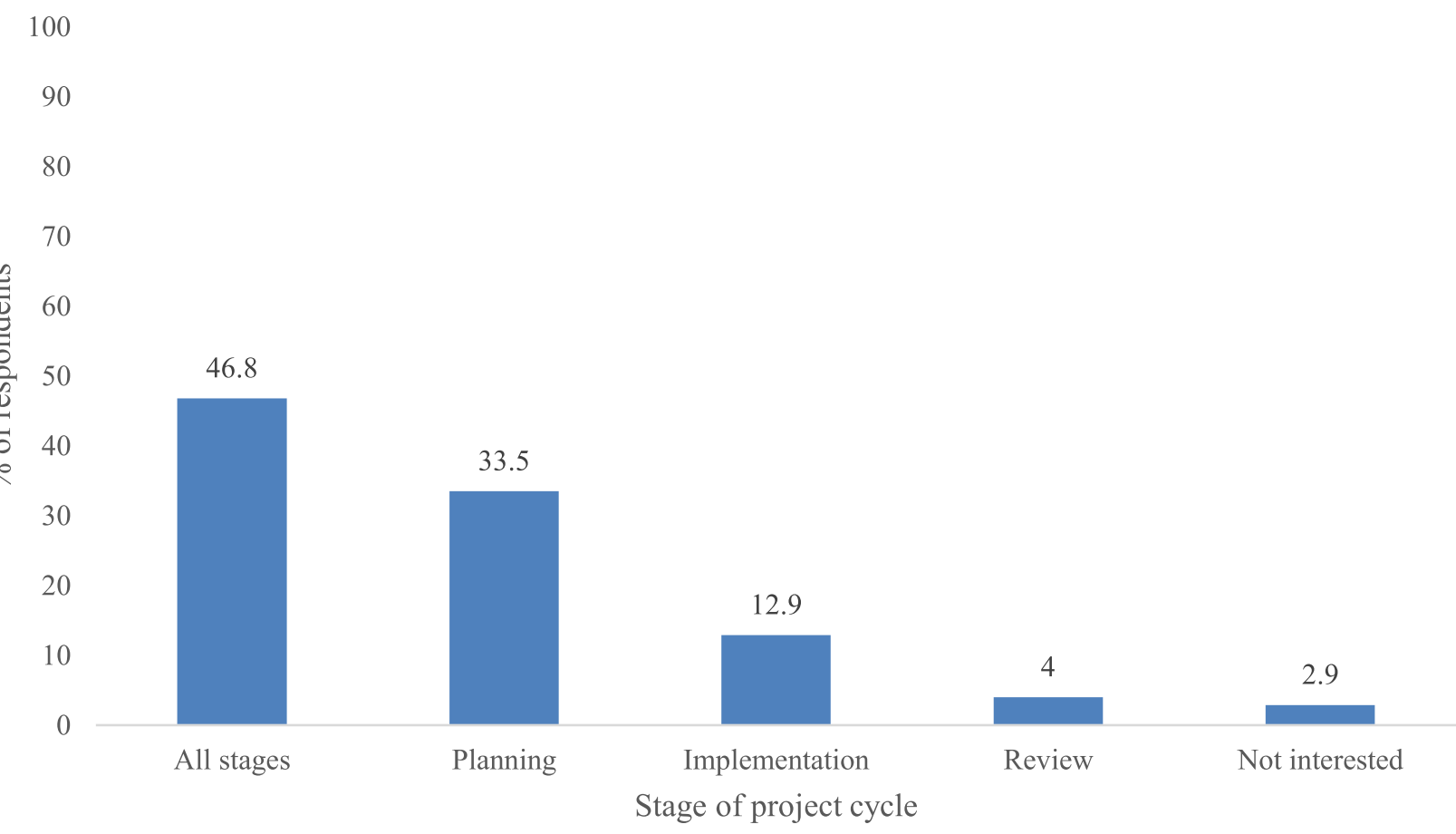

Fig. 4 Areas respondents want to be involved in interventions among IDP camp dwellers in Borno ( $n=278)$ 
Table 6 Respondents desire to participate in the intervention against ever benefitting from any intervention in the camp ( $n=278$ )

\begin{tabular}{lll}
\hline $\begin{array}{l}\text { Preferred } \\
\text { stage of } \\
\text { involvement }\end{array}$ & $\begin{array}{l}\text { Ever benefitted from the intervention } \\
\text { Frequency (\%) }\end{array}$ & Statistics \\
\hline Planning & $90(96.8)$ & 56.950 \\
Implementation & $30(100.0)$ & \\
Review & $9(81.8)$ & \\
All the stages & $119(91.5)$ & \\
\hline
\end{tabular}

*Statistically significant at $95 \% \mathrm{Cl}$

distribution was the intervention from which most (71.9\%) respondents benefitted. This finding agrees with the DTM (2020) report that over $80 \%$ of the IDP camp dwellers responded to receiving food at least once over the last 12 months, and 55\% of them benefitted from food distribution during the previous 2 months. Onethird of those who had benefitted from food incentives reported that the distribution was irregular, while $48 \%$ noted that food distribution is monthly (DTM 2020. Lenshie (2016) also reported that besides education, nutrition was the highest requirement among IDPs. Only $4.7 \%$ of the respondent reported having benefitted from the supply of farming implements, including receiving seedlings. This finding is supported by the DTM (2020), which highlighted that farming was not a top priority among IDP camp dwellers as most of them were involved in petty trading and daily laborer works.

From the findings, $96.5 \%$ of the female respondents have benefitted from at least one of the listed interventions, which was statistically significant $(p<0.05)$. There was a statistically significant $(p<0.05)$ relationship between receiving at least one intervention and marital status. Over $90 \%$ of the married respondents (currently married, divorced, and widowed) had benefitted from at least one intervention since their arrival in the camp compared to those who were single at the time of the survey. Also, more (93.3\%) caregivers who had children had benefitted from at least one intervention compared with those who had no children $(80.0 \%)$; this relationship was statistically significant $(p<0.05)$. Distribution of

Table 7 Respondents desire to participate in the intervention against satisfaction with the intervention received $(n=156)$

\begin{tabular}{lll}
\hline $\begin{array}{l}\text { Preferred stage of } \\
\text { involvement }\end{array}$ & $\begin{array}{l}\text { Satisfied with } \\
\text { intervention } \\
\text { Frequency (\%) }\end{array}$ & Statistics \\
\cline { 2 - 3 } & $57(98.3)$ & $1.021 \quad 0.907$ \\
\hline Planning & $27(100.0)$ & \\
Implementation & $3(100.0)$ & \\
Review & $65(97.0)$ & \\
All the stages & $1(100.0)$ & \\
Not interested & & \\
\hline
\end{tabular}

relief materials under the circumstances such as seen among IDPs prioritize the vulnerable groups (Davies 2012), including women, beneficiaries with children, and the aged as seen in this study.

Out of the interventions provided, $47.7 \%$ were satisfied with nutrition and food distribution. About $77 \%$ of the respondents were very satisfied with the interventions they had received. This finding is attributable to the fact that they were in line with the respondents' desire, as identified by DTM (2020).

Among the respondents who had benefitted from at least one intervention, $60.9 \%$ have been contacted previously about the project. Among those previously informed, $41.7 \%$ were told at the planning stage, while about a third $(34.0 \%)$ of respondents were informed in all the implementation stages. These findings agree with Bappi et al. (2018) that most project beneficiaries are involved in the projects just for consultation and information but not as stakeholders in the project cycle. Greater than $90 \%$ of beneficiaries involved in planning, implementation, and all stages of the interventions had benefitted from at least one intervention. In the same vein, $90 \%$ of the respondents were satisfied with the intervention, but this finding was not statistically significant $(p>0.05)$. These findings are in line with reports by other researchers who had stated that when beneficiaries are carried along and made stakeholders in the project cycle components, they become more satisfied and are more likely to own and sustain the interventions (Claridge 2004; Efuntoye 2015). The correlation between the duration of stay in the camp and satisfaction indicated that the longer the duration of staying on the camp, the more satisfied they were because they may have adjusted their lifestyles to live within the means of camp provision.

\section{Conclusion and recommendations}

Over $90 \%$ of the IDPs interviewed benefitted from the interventions provided to the IDP camps surveyed. Distribution of food items was the most widereaching intervention as about $79 \%$ reported being beneficiaries of the intervention. More female respondents, and ever married (married, divorced, and widowed) respondents, and respondents who had 
children in the IDP camps reported having benefitted from the intervention compared to their respective counterparts. About two-thirds of the beneficiaries were contacted before the intervention commenced, while $41.7 \%$ were contacted during the planning stage alone. Only about one-third (34.0\%) were engaged at all the stages of the interventions. Over $90 \%$ of the respondents involved in all the stages, planning and implementing the intervention, benefitted from the interventions compared to respondents involved in the review only.

There is a need to involve beneficiaries in IDP camps in project planning, implementation, and review more adequately to improve development projects effectiveness and efficiency. This is because IDP camp dwellers may have diverse needs which may not be adequately addressed if blanketed projects are designed without the beneficiaries' participation could reduce the project's level of impact and acceptability.

\section{Acknowledgements}

The authors acknowledge the contributions of Dr. Misali AkhanKskbiya, Fatima El-Yakub, and Alhaji Dalhatu for their contribution during data collection.

\section{Authors' contributions}

Igbaver Isaac leren: He led the research team, coordinated data analysis, and drafted this manuscript. He is also the corresponding author. Salome KabukAgbadu: She led the data collection effort, reviewed the research tool, supported data cleaning, and reviewed the draft of the manuscript. Chukwuma Umeokonkwo: Dr. Chukwuma supported the review of the research manuscript, guided the data analysis, and continued to provide support to shape the manuscript. The authors read and approved the final manuscript.

\section{Funding}

There was no source of funding from outside to support this work. The entire work and its documentation are the sole efforts of the authors.

\section{Availability of data and materials}

The data that support the findings for this research work is available to third party upon written request to the corresponding author.

\section{Declarations}

\section{Competing interests}

The authors declare that they have no competing interests in this work and that every author has read and agreed to the quality of what is being documented.

\section{Author details}

${ }^{1}$ African Field Epidemiology Network, Abuja, Nigeria. ${ }^{2}$ Centre of Excellence for Development Communication, Ahmadu Bello University, Zaria, Nigeria. ${ }^{3}$ Federal Teaching Hospital, Abakaliki, Nigeria.

Received: 22 October 2020 Accepted: 12 April 2021 Published online: 03 May 2021

\section{References}

Abdullahi MB, Ahmed A, Sale I (2014) Community participation and project sustainability in rural Nigeria: a study of Bauchi State Local Empowerment and Environmental Management Project. Afr J Sustainable Dev 4(1) https:// www.ajol.info/index.php/ajsd/article/view/106781. print ISSN: 2315-6317

Adewale S (2016) Internally displaced persons and the challenges of survival in Abuja. Afr Secur Rev 25(2):176-192. https//doi.org/10.1080/10246029.2016.1154475
Akuto GW (2017) Challenges of internally displaced persons (IDPs) in Nigeria: implications for counselling and the role of key stakeholders. Int J Innovative Psychol Soc Dev 5(2):21-27 ISSN: 2467-8546

Albert IO (2017) Rethinking the functionality of the multinational joint task force in managing the Boko Haram Crisis in the Lake Chad Basin. Afr Dev XLII(3): 119-135

Assessment Capacities Project (ACAPS, 2017). Thematic Report; Health in the Northeast. Available 24th May 2017 on https://www.acaps.org/sites/acaps/ files/products/files/20170524_acaps_thematic_report_health_in_northeast_ nigeria.pdf.

Babagana A. (2017). Origin and meaning of Borno. Available 10-03-2020 at https://www.researchgate.net/publication/320808718_ORIGIN_AND_MEA NING_OF_BORNO/link/5a01e8034585155c96ca0e15/download

Bappi U, Singh D, Dahiru K (2018) The effect of community participation on community development in Nigeria. Int J Adv Arts Sci Eng 6(13):48-60

Chama C, Mairiga A, Geidam A, Bako B (2010) An assessment of policies and programs for reducing maternal mortality in Borno State, Nigeria. Afr J Reprod Health 14(3):49-54

Chirenje LI, Giliba RA, Musamba EB (2013) Local communities' participation in decision-making processes through planning and budgeting in African countries. Chin J Popul Resour Environ 11(1):10-16. https://doi.org/10.1080/1 0042857.2013 .777198

Claridge T (2004) Designing social capital sensitive participation methodologies. Soc Cap Res Available August 16, 2020, on https:/d1fs2th61 pidml.cloudfront.net/ wp-content/uploads/2013/01/Social-Capital-and-Participation-Theories.pdf

Davies, A. (2012). IDPs in host families and host communities: assistance for hosting arrangements. Division of International Protection Protection Operational Support. Available on 07-09-2020 at https://www.refworld.org/ pdfid/4fe8732c2.pdf

Displacement Tracking Matrix DTM (2020) Northeast Nigeria: displacement report 32 (June 2020); assessment on displacement trends in the six conflictaffected states. International Organization for Migration (IOM) Available 0709-2020 at https://reliefweb.int/sites/reliefweb.int/files/resources/DTM\%2 OReport\%20Round\%2032.pdf

Efuntoye A (2015) Community participation in health care: issues and challenges in Nigeria. South Am J Acad Res 2(1):1-10

Gilbert LD (2014) Prolongation of Boko Haram Insurgency in Nigeria: the international dimensions. Res Humanit Soc Sci. 4(11):150-156

Laah ED, Adefila JO, Yusuf RO (2014) Community participation in sustainable rural infrastructural development in Riyom area, Plateau State of Nigeria. J Econ Sustainable Dev 5(4):49-57 mww.iliste.org ISSN 2222-1700 (Paper) ISSN 2222-2855

Lenshie N (2016) Boko Haram insurgency, internally displaced persons and humanitarian response in Northeast Nigeria. Int J Humanit Soc Stud. 4:141150 ISSN 2321 - 9203

Mohammed F. K. (2017). The causes and consequences of internal displacement in Nigeria and related governance challenges. Working Paper Division Global Issues Stiftung Wissenschaft und Politik German Institute for International and Security Affairs. Available 6-09-2020 at https://www.swpberlin.org/filea dmin/contents/products/arbeitspapiere/Mohammed_2017_Internal_Displa cement_Nigeria.pdf

OCHA (UN Office for the Coordination of Humanitarian Affair) (2017). Community engagement at the centre of disaster response. News \& Updates. Available online https://www.unocha.org/story/community-engagement-centre-disa ster-response

OCHA (UN Office for the Coordination of Humanitarian Affair) (2019). 2019 Humanitarian needs overview, Nigeria. Available on https://www.unocha.org/nigeria

Ofuoku AU (2011) Effect of community participation on sustainability of rural water projects in Delta Central agricultural zone of Delta State, Nigeria. J Agric Ext Rural Dev 3(7):130-136 Available online http://academicjournals. org/JAERD ISSN-2141-2154

Olanrewaju FO, Omotoso F, Alabi JO (2018) Datasets on the challenges of forced displacement and coping strategies among displaced women in selected internally displaced persons' (IDPS) camps in Nigeria. Data Brief 20:152-158 https://doi.org/10.1016/j.dib.2018.07.042

Olori CN, Okide CC (2014) Achieving sustainable community development projects through community participation in Rivers State, Nigeria. J Educ Pract 5(24):9399 www.iiste.org ISSN 2222-1735 (Paper) ISSN 2222-288X (Online)

Oyefara JL, Alabi BO (2016) Socio-economic consequences of developmentinduced internal displacement and the coping strategies of female victims in Lagos Nigeria: an ethno-demographic study. Afr Popul Stud 30(2):2520-2532 http://aps.journals.ac.za 
Shehu M, Abba A (2020). https://doi.org/10.1186/s41018-020-00084-2) Humanitarian crisis and sustainable development: perspectives and preferences of internally displaced persons in northeastern Nigeria. Int J Humanitarian Action 5(1):17

Shuaibu SS, Salleh MA, Shehu AY (2015) The impact of Boko Haram Insurgency on Nigerian National Security. Int J Acad Res Bus Soc Sci 5(6):254-266

Surajo AZ, Umar AS, Musa J, Haruna MJ (2019) Displaced persons in NorthEastern Nigeria: causes, effects and the role of social workers. Soc Anthropol 8(3):57-65. https://doi.org/10.13189/sa.2020.080301

Thwala WD (2010) Community participation is a necessity for project success: a case study of rural water supply project in Jeppes Reefs, South Africa. Afr J Agric Res 5(10):970-979. Available online at http://www.academicjournals. org/AJAR. https://doi.org/10.5897/AJAR09.700

\section{Publisher's Note}

Springer Nature remains neutral with regard to jurisdictional claims in published maps and institutional affiliations.

\section{Submit your manuscript to a SpringerOpen ${ }^{\circ}$ journal and benefit from:}

- Convenient online submission

- Rigorous peer review

- Open access: articles freely available online

High visibility within the field

- Retaining the copyright to your article

Submit your next manuscript at $\boldsymbol{\wedge}$ springeropen.com 